\title{
Improving Learning Outcomes of Motion Short Distance Run with The Basic Approach to Play
}

\author{
Eka Purnama Indah \\ Physical EducationJPOK FKIP \\ Lambung Mangkurat University \\ Banjarbaru, Indonesia \\ eka.indah@ulm.ac.id
}

\author{
Endang Pratiwi \\ Sport Education \\ Universitas Islam Kalimantan Muhammad Arsyad \\ Al Banjari, Banjarmasin, Indonesia \\ pratiwiendang@uniska.bjm.ac.id
}

\begin{abstract}
This study aims to determine the basic learning outcomes of short distance running with the approach of playing students at TK Taruna Banjarmasin, South Borneo, through the play approach. This research is a classroom action research. The study was conducted in two cycles, which consisted of planning, observation, action, and reflection design. The targets in this study were students of grade playgroup ages 5-6 years at TK Taruna Banjarmasin South Borneo, totaling 32 students. Sources of data obtained through preliminary tests and final tests of basic learning skills of short-distance running. The data analysis technique used in this study is descriptive. The results showed from the initial test to the final test. Initial test results show the lowest value of 41.7 and the highest value of 66.7. Then the final test results in the first cycle, namely the lowest value of 50 and the highest value of 83.3 and still $59.90 \%$. Learning is increasing in the second cycle with the lowest value of 50 and the highest 91.7, with a percentage of $81.25 \%$, and has met the criteria for achievement in action research that is $80 \%$. The conclusion of this study is that the learning method of playing has a very positive effect on elementary school-age children in improving student learning achievement, which is marked by an increase and completeness in learning.
\end{abstract}

Keywords-: Approach to Play, Learning Outcomes, Basic Motion for short distance running

\section{INTRODUCTION}

Physical education can provide opportunities for students to learn a number of important things. However, not all physical education teachers are aware of this, so many assume that physical education may be done haphazardly. This is reflected in various negative things about physical education lessons, starting from the weaknesses of the resident process, for example letting students play alone to the low quality of learning outcomes and physical fitness and still very low motion development in children. In physical education learning, children are trained to develop locomotor, non-locomotor and manipulative basic motion skills. From these three types of basic mobility abilities, they can later be developed according to the talents of the child. Therefore a teacher must be able to develop a variety of materials that can make students move and practice their basic ability to move. During this physical education learning process that is applied in primary school is still far as we expected, the process of physical education in elementary school has not led to how to improve movement skills by not eliminating the element of playing in children, this is where the role of physical education teachers must be used and utilized to be able to improve the development of motion in children by applying game models that can grow and develop basic motion, both games that are done in teams, in pairs, or individually. With the problems in the background above, the authors conclude that the necessary application of learning actions that can provide learning motivation and benefits, interesting and effective in basic motion learning and provide convenience to physical education teachers in delivering material To overcome this the writer wants to apply the model play approach to improve learning outcomes for basic motion (walking, running and jumping) in TK Taruna Banjarmasin schools.

Children at this age are classified as happy to play, therefore every material to be provided must be endeavored to have a playful element that is fun, but still does not leave the subject matter about what the child wants to achieve. With the creation of a sense of pleasure and excitement when learning physical education, it will naturally raise motivation in children to continue to follow learning activities, especially in the field of physical education. Based on the above explanation it can be concluded that a play approach is an approach that emphasizes more on the situation to solve problems that arise. This is the motivation and curiosity of the author to further examine how the effort to overcome the difficulties of mastering the learning of basic short-distance motion through a play approach in early childhood. Action research is a research process that begins by discovering practical problems in the classroom, then solving them by taking action (action) with the aim of finding a change. The intended change is to improve the quality of learning [1].

Children like to play because in themselves there is an inner urge and the urge to develop themselves. Many scientists are interested in researching games because they realize the important role of games in development [2]. Growth is a condition that shows changes in size about increasing height and weight. Children's development basically depends on the child's efforts to develop themselves [3]. The play/activity approach, which has been exceptionally accepted in beginner athletics, is primarily designed to produce fun, challenges, creativity, problem-solving, and motivation. Children should be involved in dynamic and fun activities with lots of freedom to move. The play/activity approach will keep a team interested in athletics, will also develop the creativity of players, improve decision-making abilities, and improve their physical abilities. Sprint running is a run that is carried out as quickly as possible by deploying all abilities as much as possible. With techniques that must be understood and mastered, namely the start technique, the running technique, the technique passing the finish line. 
Based on observations in the second cycle about Running is a number called non-engineering. Because running is a relatively simple natural activity. When compared with other athletic numbers [4]. Slameto in Learning and Factors that influence learning improvement is a process of effort by someone to obtain a new change in behavior as a whole, as a result of his own experience in interacting with his environment [5].

\section{METHODS}

The research method used is the Action Research method. The implementation of the research involves colleagues as collaborators and class teachers, then researchers as implementing actions. The Kemmis and Taggart research designs include: 1) planning, 2) implementation, 3) observation, and 4) reflection [6].

Here are Stephen Kemmis and Mc Taggart's model which uses a spiral cyclical self-reflection system. As in the following picture:

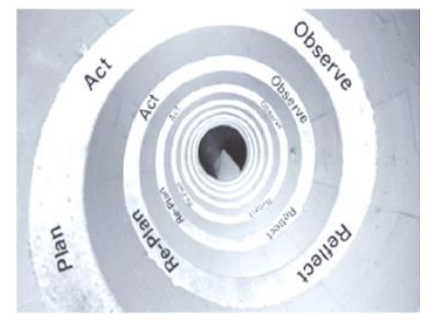

Fig. 1. Cycle of action researchSource [7]

This research was conducted in 2 cycles to get the results of learning the basic motion of short distance running according to the required value criteria of $80 \%$.

\section{RESULTS AND DisCUSSION}

\section{A. Preliminary Results of Basic Tests of Short Distance Running}

Based on observations in the first cycle about learning activities as a whole, the teacher has carried out learning activities ideally, but there are notes from collaborators that researchers must pay more attention to class conditions when students follow the game to be more orderly and organized in order to achieve learning objectives. In addition, researchers must be more creative in presenting games so that they are more varied and can provide motivation to students, especially on how to arouse student learning.

\section{B. Final Test Results of the First Cycle of the Basic Motion of Short Distance Running}

Based on observations on the results of the end of the first cycle of learning activities as a whole, the teacher has conducted learning activities ideally, but there are notes from collaborators that researchers must pay more attention to class conditions when students follow the game to be more orderly and organized in order to achieve learning objectives. In addition, researchers must be more creative in presenting games so that they are more varied and can provide motivation to students, especially on how to arouse student learning. Learning achievement has not been reached up to $80 \%$ then it will be continued with the second cycle. overall learning activities, the teacher has carried out learning activities ideally, but there are notes from collaborators that researchers must pay more attention to class conditions when students take part in the game to be more orderly and organized in order to achieve learning objectives. In addition, researchers must be more creative in presenting games so that they are more varied and can provide motivation to students, especially on how to arouse student learning. Based on the results of the basic short distance run motion evaluation as a whole evaluator, and the results of the final test in cycle I to cycle II, there were significant changes.

TABLE I. THE RESULTS OF AN INCREASE IN CYCLE I TO CYCLE II

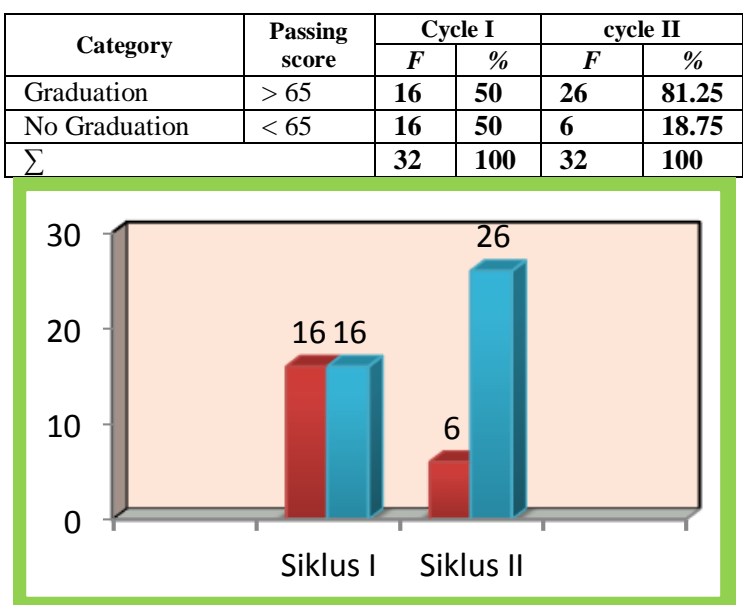

Fig. 2. The results of an increase in cycle I to cycle II

From the final test results in the first cycle to the next cycle, there was a significant change. The results of learning to run short distance running with a basic approach to playing Taruna Banjarmasin Kindergarten this like research that has been done by Aulia Akbar the application of play methods to increase student activity in participating in sports learning in kindergartens students

\section{CONCLUSION}

The results of calculations that is from the last cycle I and II tests in this study with a sample of 32 students that achieved an increase in cycle II that is $81.25 \%$ or more than half of the total sample was said to be used to perform basic short-distance running movements properly and correctly. The application of the play approach makes the learning atmosphere more active, interesting, and varied. This can be seen from the enthusiasm of students in participating in learning, and more enthusiastic. These conditions make it easier for teachers to manage to learn so that the results will be better.

\section{REFERENCES}

[1] Emzir, Metodelogi Penelitian Kualitatif dan Kuantitatif. Jakarta. Renika Cipta. 2012.

[2] Zulkifli L. Psikologi Perkembangan, Bandung: PT. Remaja Rosdakarya, 2005.

[3] Tangkudung, James dan Adhyaksa Dault. Faal Olahraga. Jakarta: Cerdas Jaya. 2006.

[4] Zafar, Siddik, Melatih Atletik. Alfabetha Bandung. 2012

[5] Slameto, Belajar dan yang mempengaruhinya. Jakarta: Reneka cipta, 2010. 
[7] Kemmis, Stephen, in Geoffrey E. Mills. Action Research: A Guide

[6] Kristyanto, Agus. Penelitian Tindakan Kelas dalam Pendidikan Jasmani dan Kepelatihan Olahraga, Surakarta: UNS Press, 2010. 